\title{
Konsep Tujuan Hidup Manusia: Tinjauan Teologis Dalam Pendidikan Islam
}

\author{
Ima Frima Fatimah \\ Program Doktor Studi Islam, Universitas Islam Negeri (UIN) Sunan Gunung Djati Bandung \\ Email: imafatimah0707@gmail.com \\ Nurwadjah Ahmad EQ \\ Universitas Islam Negeri (UIN) Sunan Gunung Djati Bandung \\ Email: nurwadjah.ahmad@gmail.com \\ Andewi Suhartini \\ Universitas Islam Negeri (UIN) Sunan Gunung Djati Bandung \\ Email: andewi.suhartini@uinsgd.ac.id \\ Received: January 29, 2020 | Accepted: June 10, 2020
}

\begin{abstract}
This article aims to elaborate the concept of the purpose of human life as a theological foundation in Islamic education. Humans created by God have a number of predetermined goals. This research approach uses a qualitative approach with literature study methods. The results showed that there are two goals in human life that are closely related to their duties and functions as God's creatures, namely as a servant of God and as a caliph on the earth. The implication of two human goals on the process of Islamic education is how the education process forms a good servant of God and as a caliph on earth who has a responsible character, so as to realize a perfect human being.
\end{abstract}

\begin{abstract}
Abstrak
Artikel ini bertujuan untuk mengelaborasi konsep tujuan hidup manusia sebagai landasan teologis dalam pendidikan Islam. Penciptaan manusia oleh Allah memiliki sejumlah tujuan. Penelitian ini menggunakan pendekatan kualitatif dengan metode studi pustaka (library research). Hasil penelitian menunjukkan terdapat dua tujuan hidup manusia berkaitan erat dengan tugas dan fungsinya sebagai makhluk Allah yaitu sebagai hamba Allah dan sebagai khalifah fi al-ardl. Dua tujuan tersebut berimplikasi terhadap proses pendidikan Islam yaitu bagaimana proses pendidikan membentuk hamba Allah yang baik dan khalifah di muka bumi yang bertanggung jawab, sehingga pada gilirannya bermuara pada terwujudnya insan kamil (manusia paripurna).
\end{abstract}

\section{Keywords}

The purpose of human life, 'âbid, khalifah fi al-ard 


\section{Pendahuluan}

Manusia diciptakan Allah untuk mengemban amanah dan menjalankan tugas sebagai khalifah fi al-ardl. Asal mula kejadian manusia menjadikan nilai lebih sebagai makhluk dibandingkan dengan yang lainnya dengan kelebihan akal dan pengetahuan yang dimilikinya. Saat Adam diciptakan Allah sebagai manusia pertama di muka bumi, Allah memerintahkan malaikat untuk bersujud karena kelebihan akal yang dimilikinya. Keistimewaan yang dimiliki manusia menjadikan makhluk yang berkualitas memberikan implikasi terhadap perbedaan tugas dan kewajibannya dengan makhluk lain. Al-Quran mengarahkan manusia untuk memahami tujuan hidupnya, baik itu kehidupan secara individu, keluarga dan bermasyarakat. Tujuan inilah yang mengarahkan manusia untuk beraktivitas dan mencapai eksistensinya dalam kehidupan. Siapa pun yang melanggar arahan ini berarti ia mengingkari eksistensi dirinya dalam kehidupan, secara tidak langsung kehidupan yang mewarnai dirinya dianggap kosong dan tidak bermakna.

Adapun tujuan hidup manusia yang cukup urgen di dalam al-Qur'an adalah berkaitan dengan tugas dan fungsinya yaitu sebagai hamba dan khalifah di muka bumi. Hal ini senada dengan pernyataan yang diungkap oleh Ibrahim Bafadhol, berdasarkan hasil penelitiannya bahwa tujuan hidup manusia pada akhirnya adalah untuk beribadah kepada Allah dengan pemaknaan yang sangat luas, artinya tidak terbatas kepada ritual keagamaan, akan tetapi kehidupan sosial, ekonomi, budaya dan pendidikan termasuk pada kategori ibadah (Bafadhol, 2017, pp. 25-38). Penelitian lain diungkap oleh Sitti Trinurmi merelevansikan tujuan hidup manusia dengan tujuan pendidikan Islam yaitu mendidik individu yang saleh dengan memperhatikan perkembangan rohaniah, emosional, sosial, intelektual dan fisik, mendidik anggota kelompok sosial yang saleh, baik dalam keluarga maupun masyarakat muslim (Trinurmi, 2015, p. 57). Al-Ghazali menganalisis bahwa tujuan pendidikan Islam dikaitkan dengan tujuan hidup manusia yaitu untuk mencapai kesempurnaan manusia dalam taqarrub (mendekatkan diri) kepada Allah dan mencapai kebahagiaan dunia-akhirat. Sayyid Quthb menguatkan pendapat al-Ghazali tersebut dengan menyatakan bahwa tujuan pendidikan adalah mewujudkan manusia yang baik (Trinurmi, 2015, p. 58). Terdapat pendapat pula terkait dengan tujuan hidup manusia yaitu selamat dan bahagia dunia-akhirat (Sukino, 2018, p. 63). Pernyataan demikian tentu tidak terlepas dari aspek manusia sebagai abid (hamba Allah) dan khalifah fi al-ardh.

Istilah hamba (abid) dimaknai sebagai "hamba Allah" yaitu orang-orang yang bersungguh-sungguh dalam beribadah dengan kaidah yang telah ditentukan oleh syari'at. Kata "abid" berarti pula orang yang bersungguh- 
sungguh dalam beribadah meskipun hanya bersifat lahiriah. Dengan istilah lain bahwa abid adalah orang yang bersungguh-sungguh dalam beribadah sesuai dengan kaidah syari'at namun hanya sebatas lahiriah. Sedangkan orang yang beribadah secara lahir dan batin disebut 'alim (Mujieb, 2009, p. 9). Seorang hamba akan mampu menjalankan kehidupannya dengan baik selama ia memahami dan mengaplikasikan konsep tersebut. Sehingga kata ábid masih seakar kata dengan "ibadah", ibadah menurut bahasa berasal dari kata abadaya'budu-ibadatan artinya taat, tunduk dan patuh. Ibadah merupakan sarana atau media untuk menggapai tujuan hidup manusia, ibadah yang dimaksud adalah ibadah secara universal tidak sekadar slogan dan simbol semata. Menunaikan ibadah sebagai khalifah di muka bumi merupakan esensi dari makna ibadah (Jazuli, 2006, p. 509). Yusuf Qardhawi menjelaskan bahwa ibadah merupakan puncak ketaatan tertinggi yang berasal dari kesadaran hati sanubari dalam mengagungkan yang disembah. Ibnu Taimiyah menegaskan makna ibadah dengan ungkapan semua bentuk cinta dan keteladan kepada Allah baik lahir maupun batin. Misalnya shalat, zakat, puasa, ibadah haji, menjalankan amanah, berbuat baik kepada kedua orang tua, menjalin silaturahim, amar ma'ruf nahy munkar, zikir, sabar, peduli kepada yatim piatu dan lain-lain sebagainya (Sutisna, 2015, pp. 34-35).

Manusia berdasarkan tujuan hidup yang telah diungkap di atas, selain hamba (abid) adalah khalifah fi al-ardh. Secara etimologis kata khalifah berasal dari kata khalafa yang berarti menggantikan tempat seseorang sepeninggalnya. Kata khalif atau khalifah berarti seorang pengganti, dengan inilah kata khulafa dan khalif sebagai bentuk jamak dari kata khalifah telah disebutkan dalam alquran. Kaitannya dengan kedudukan manusia sebagai khalifah fil ardl kata khalifah mempunyai makna wakil, pengganti tuhan di muka bumi, pengganti nabi Muhammad saw sebagai kepala pemerintahan (Priatna, 2005, p. 72). Khalifah dapat dimaknai sebagai pengganti nabi Muhammad saw dalam fungsinya sebagai kepala negara, kepala pemerintahan baik yang menyangkut urusan agama dan dunia. Sejarah Islam menyebutkan istilah khalifah menjadi khalifaturrasul sebagai sebutan untuk Abu Bakar dan khalifah-khalifah rasul Allah sebagai sebutan untuk Umar Bin Khattab. Semua pandangan mengenai makna khalifah mengisyaratkan bahwa khalifah mempunyai makna sebagai orang yang menggantikan. Abdullah mengklasifikasikan pandangan tersebut dalam tiga pendapat yaitu: pertama, manusia merupakan spesies yang menggantikan spesies lainnya yang lebih dulu hidup di bumi. Kedua, istilah khalifah digunakan kepada kelompok manuasia yang menggantikan kelompok lainnya. Ketiga, khalifah tidak hanya merujuk kepada pengertian pengganti atau pengikut jejak tetapi lebih dimaknai sebagai pengganti Allah (Priatna, 2005, pp. 72-73). 
Pemaparan di atas dapat ditarik benang merah bahwa pengertian khalifah sebagai wakil Tuhan di muka bumi merunjuk pada pengertian individual yang dapat dimiliki oleh setiap manusia. Semua manusia berhak mendapatkan kedudukan yang sama, hanya kualifikasi kekhalifahannya yang akan menunjukkan sejauh mana optimalisasi potensi kemanusiaanya. Secara struktural al-Qur'an menyebut manusia sebagai nafs yang terbentuk dari unsur jasad, hayat dan ruh. Pada tahapan fungsional al-Qur'an menyebut manusia sebagai 'abd dan khalifah $f i$ al-ardh. Esensi dari kedudukannya sebagai 'abdullah meniscayakan akan ketaatan tunduk dan patuh kepada sang pencipta, sementara dilihat dari esensi kedudukannya sebagai khalifah meniscayakan kebebasan dan kreativitas manusia dalam membentuk kebudayaan atau satu proses perwujudan eksistensi manusia.

Penulis mengidentifikasi beberapa tugas dan fungsi manusia sebagai khalifah dalam pengertian wakil atau pengganti yang memegang kekuasaan dan sebagai hamba Allah. Kedua poin tersebut memiliki konsekuensi moral sehingga kehidupan manusia dibatasi oleh nilai dan etika ketuhanan. Manusia tidak diperkenankan menentang hukum Allah yang telah ditetapkan melainkan taat akan ketetapannya. Manusia harus mengiternalisasikan tugas kebudayaan dengan ciri kreativitas pada kehidupannya dan senantiasa menciptakan sesuatu yang baru sesuai dengan kebutuhan dan perkembangan masyarakat. Manusia bertugas mensyukuri nikmat yang diberikan Allah dengan upaya berkarya memakmurkan dan membudayakan bumi. Tugas terakhir inilah secara implisit menggambarkan konsep metafisis-antropologis Islam tentang manusia dengan pandangan positif dan konstruktif. Islam tidak hanya menempatkan manusia secara simplikatif sebagai bagian dari realitas makro kosmos, lebih jauh Islam menuntut peran kreatif manusia untuk mengelola alam dan sumber daya material dalam rangka pengabdian akan tugas kemanusiaan.

Usaha manusia menyiapkan diri dan mengembangkan potensinya agar sampai pada kedudukan pembawa amanah, tidak dapat bekerja sendiri tanpa memanfaatkan bimbingan Allah. Manusia diberikan fitrah yang dibawa sejak lahir membantu manusia memperoleh pengetahuan dan peradaban dalam memahami kekhalifahannya. Kemampuan psikologis dan fisiologis yang dimiliki manusia dapat dikembangkan secara optimal, sehingga menjadi alat yang berguna dalam melaksanakan tugas pokok kehidupannya di dunia. Pendidikan menjadikan sarana atau alat yang menentukan sejauh mana titik optimal fitrah tersebut dapat dicapai. Melalui pendidikan manusia memperoleh pengetahuan untuk memilih perilaku yang baik dan yang buruk. 


\section{Metode}

Penelitian ini menggunakan pendekatan kualitatif dengan metode studi pustaka (library research). Sejumlah ayat Al-Qur'an yang mengandung penjelasan teologis-filosofis dihimpun dan dipilah secara maudhu'i, untuk kemudian dipetakan sesuai dengan kerangka kajian. Kelompok ayat-ayat tersebut dicoba dicari tafsirannya secara tahlili sebagaimana ditemukan pada kitab-kitab tafsir mu'tabar. Lantas tafsiran kandungan ayat-ayat Al-Qur'an tersebut dicoba diverifikasi, diperdalam, sekaligus diperkaya dengan jabaranjabaran wahyu sebagaimana ditemukan pada hadis-hadis yang relevan.

\section{Hasil dan Pembahasan}

Tinjauan al-Quran terhadap konsep tujuan hidup manusia bisa dilihat dari dua sudut pandang, yaitu sudut pandang makhluk dengan khaliq serta hubungan makhluk dengan makhluk lainnya. Kedudukan manusia dalam alQuran yaitu sebagai abid (hamba) dan khalifah fi al-ardh. Sebagimana firman Allah dalam al-Qur'an surat Adz-Dzariyat ayat 56:

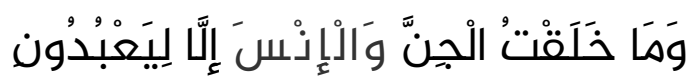

Dan aku tidak menciptakan jin dan manusia melainkan supaya mereka mengabdi kepada-Ku.

\section{Tafsir Surat Adz-Dzariyat ayat 56}

Sesungguhnya Allah menciptakan jin dan manusia agar mereka menyembah Allah, bukan karena Allah membutuhkan mereka. Ali Ibnu Abu Talhah telah meriwayatkan dari Ibnu Abbas lafadz illa liya'budun bermakna agar mereka mengakui kehambaan kepada Allah, baik dengan sukarela maupun terpaksa. Demikianlah menurut apa yang dipilih oleh Ibnu Juraij, makna yang dimaksud ialah melainkan supaya mereka mengenal-Ku (Allah). As-Saddi mengungkapkan bahwa sebagian dari pengertian ibadah ada yang bermanfaat dan sebagian lainnya ada yang tidak bermanfaat (Katsir, 2004, p. 16). Ayat di atas sesuai berdasarkan penafsiran Quraish Shihab yaitu bertujuan menekankan pesan yang dikandungnya tetapi juga untuk mengisyaratkan bahwa perbuatanperbuatan Allah melibatkan malaikat atau sebab-sebab lainnya. Penciptaan, pengutusan Rasul, turunnya siksa, rezeki yang dibagikan Allah melibatkan malaikat dan sebab-sebab lainnya, sedang di sini karena penekanannya adalah beribadah kepada Allah, semata-mata tanpa memberi kesan adanya keterlibatan selain Allah. Surat Adz Dzariyat ayat 56 didahulukannya penyebutan kata al- 
jinn dari kata al-ins karena memang jin lebih dahulu diciptakan Allah dari pada manusia.

Ibadah bukan sekadar ketaatan dan ketundukan, tetapi menyembah adalah suatu bentuk ketundukan dan ketaatan yang mencapai puncaknya akibat adanya rasa keagungan dalam jiwa seseorang terhadap siapa yang kepadanya mereka mengabdi. Ia juga merupakan dampak dari keyakinan bahwa pengabdian itu tertuju pada yang memiliki kekuasaan yang tidak terjangkau arti hakikatnya. Begitu lebih kurang tulis Syeikh Muhammad Abduh. Ibadah terdiri dari ibadah murni (mahdhah) dan ibadah tidak murni (ghairu mahdhah). Ibadah mahdhah adalah ibadah yang telah ditentukan oleh Allah, bentuk, kadar, atau waktunya, seperti shalat, zakat, puasa dan haji. Ibadah ghairu mahdhah adalah segala aktivitas lahir dan batin manusia yang dimaksudkannya untuk mendekatkan diri kepada Allah. Hubungan seks pun dapat menjadi ibadah, jika itu dilakukan sesuai tuntunan agama. Nah, ayat diatas menjelaskan bahwa Allah menghendaki agar segala aktivitas manusia dilakukan demi karena Allah yakni sesuai dan sejalan dengan tuntunan petunjuk-Nya. Quraish Shihab mengutip pendapat Thabathaba'I yang memahami huruf lam pada ayat yang ditafsirkan ini dalam arti agar supaya yakni tujuan penciptaan manusia dan jin adalah untuk beribadah. Ulama menulis bahwa tujuan apapun bentuknya adalah sesuatu yang digunakan oleh yang bertujuan itu untuk menyempurnakan apa yang belum sempurna baginya atau menanggulangi kebutuhan atau kekurangannya. Tentu hal ini mustahil bagi Allah, karena Allah tidak memiliki kebutuhan. Dengan demikian tidak ada bagi Allah yang perlu disempurnakan atau yang perlu ditanggulangi.

Kemudian tinjuan berikutnya adalah manusia sebagai khalifah fi al-ardh. Ditinjau dari segi kedudukan manusia sebagai khalifah, Allah berfirman:

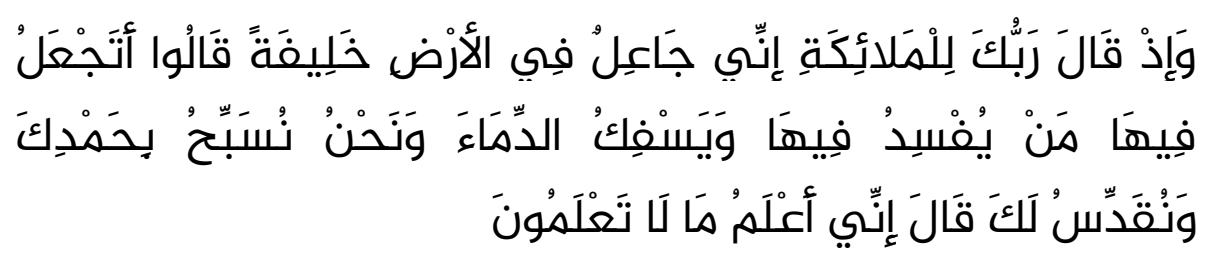

Ingatlah ketika Tuhanmu berfirman kepada Para Malaikat: "Sesungguhnya aku hendak menjadikan seorang khalifah di muka bumi." mereka berkata: "Mengapa Engkau hendak menjadikan (khalifah) di bumi itu orang yang akan membuat kerusakan padanya dan menumpahkan darah, Padahal Kami Senantiasa bertasbih dengan memuji Engkau dan menyucikan Engkau?" Tuhan berfirman: "Sesungguhnya aku mengetahui apa yang tidak kamu ketahui."( Q.S. al-Baqarah: 30) 


\section{Tafsir Q.S Al-Baqarah ayat 30}

Para mufassir berbeda pendapat terhadap telaah firman Allah tersebut: Pertama, lafadz واذ قال ربك للملائكةAllah memberitahukan tentang penganugerahan karunianya kepada anak cucu Adam yaitu berupa penghargaan sebagai makhluk yang paling mulia dibandingkan dengan para malaikat dan makhluk lainnya.

Memaknai ayat al-Qur'an di atas, para ulama memiliki dua cara dalam menyikapi wahyu tersebut yaitu: 1) para ulama salaf menerima berita wahyu dan tidak mempertanyakan persoalan secara global. Allah berkenan menceritakan wahyu mengenai hal yang ghaib dengan kalimat yang tidak difahami manusia, sementara akal manusia tidak bisa menembus secara mendalam terhadap perkara yang ghaib, dengan keyakinan dan keimanan manusia bisa mempercayai adanya wahyu. 2) ulama khalaf berpendapat apa yang disampaikan Allah kepada malaikat tidak seperti yang manusia pikirkan. Pertemuan Allah dengan malaikat tidak terjadi di suatu tempat melainkan di tempat yang berbeda, jika terjadi pada suatu tempat tentunya Allah sama seperti manusia. Malaikat tiadalah duduk berhadapan dan bertatap muka dengan Allah karena tentunya kedudukannya akan sama.

Kedua, lafadz نانى جاعل فى الارض خليفةyaitu suatu kaum yang bergenerasi, di muka bumi manusia akan berketurunan dan bergenerasi secara terus menerus. Maksud lafadz ini bahwa Allah tidak hanya menghendaki adam saja melainkan ada makhluk lain dari jenis adam yang akan melakukan hal tersebut, seolah-olah malaikat mengetahui dengan ilmu khusus perihal kata khalifah yaitu orang yang memutuskan perkara diantara manusia tentang kedzaliman yang terjadi dan mencegah mereka dari perbuatan dosa. Ucapan malaikat bukan sebagai penentang atau kedengkian terhadap Allah akan tetapi mereka disifati Allah sebagai makhluk yang tidak mendahuluinya dengan ucapan, yaitu tidak menanyakan sesuatu terhadap yang tidak diizinkan. Informasi yang diberikan melainkan mencari hikmah atas pengumuman yang diberikan, seolah malaikat bertanya mengenai hikmah penciptaan manusia secara bergenerasi sehingga menimbulkan kekhawatiran manusia berbuat kerusakan dan pertumpahan darah. Menurut Qatadah tatkala Allah memberitahukan kepada malaikat akan penciptaan makhluk di bumi, mereka sudah mengetahui terlebih dahulu dan para malaikat bertanya alasan diciptakan manusia yang akan membuat kerusakan dan kekacauan di muka bumi (Katsir, 2004, pp. 100101) .

Hemat Ibnu Katsir bahwa jawaban Allah seperti yang disebutkan dalam ayat tersebut mengandung makna Allah lebih mengetahui maslahat yang lebih besar dibalik penciptaan manusia dibandingkan dengan prediksi malaikat tentang kerusakan yang akan diciptakan manusia di muka bumi. Salah satu 
bentuk maslahat besar dibalik penciptaan tersebut yaitu Allah mengutus nabi dan rasul untuk memberi nasihat dan peringatan kepada kaumnya untuk tidak berbuat keji dan munkar. Sebagaimana firman Allah dalam surat Al-Anbiya ayat: 107 :

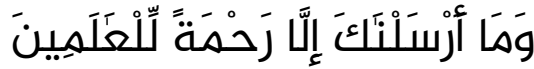

Dan tiadalah Kami mengutus kamu, melainkan untuk (menjadi) rahmat bagi semesta alam.

Ayat ini mengisyaratkan bahwa Allah mengutus diantara manusia yaitu nabi muhammad untuk mengatur dan mengelola alam agar terhindar dari kerusakan moral. Nabi diutus di tengah masyarakat jahiliyah dengan kondisi masyarakat penuh penyembahan, rusak moral, perbudakan dan penindasan. Begitulah Allah mengutus Muhammad dilengkapi dengan akhlak mulia dan teladan bagi umatnya.

Dalam hadits shahih ditegaskan bahwa malaikat naik menghadap Allah dengan membawa amal manusia. Mereka datang kemuka bumi ketika manusia mengerjakan shalat dan meninggalkannya ketika mengerjakan shalat pula. Mereka datang silih berganti dan mengawasi manusia ketika berkumpul pada waktu shalat Shubuh dan shalat Ashar. Sebagian mereka tetap mengawasi dan sebagiannya lagi naik menghadap Allah dengan membawa amal kebaikan dan keburukan.

Penafsiran di atas menegaskan bahwa segala tingkah laku manusia di bumi akan ada yang mengawasi, merekalah malaikat yang akan datang secara bergantian mengawasi perbuatan manusia. Mereka datang dan berkumpul ketika dalam keadaan shalat dan bertasbih memuji Allah. Mereka juga meninggalkannya dalam keadan shalat pula.

Ketiga, lafadz ونحن نسبح بحمدك ونقدس لك menurut Abd Ar-razaq dari Muammar dari Qatadah bahwa tasbih adalah tasbih, sedangkan taqdis adalah shalat. Ibnu Jarir mengatakan taqdis berarti pengagungan dan penyucian, senantiasa menyucikan dan menjauhkan dari perbuatan orang musyrik.Pendapat lain menyebutkan makna lafadz di atas mengandung arti selalu bertasbih memuji dan mengagungkan asma Allah. Malaikat merasa lebih layak menjadi khalifah di muka bumi karena mereka selalu bertasbih dan menyucikan Allah dibanding Adam dan keturunannya yang akan membuat kerusakan di muka bumi (Al-Mahalli, tt, p. 6).

Keempat, lafadz انى اعلم مالا تعلمون merupakan jawaban atas pertanyaan para malaikat. Maksud lafadz ini bahwa dalam penciptaan manusia terdapat kemaslahatan yang lebih besar dibanding kerusakan yang dikhawatirkan. Allah akan menjadikan di antara manusia para nabi dan rasul, siddiqun, syuhada, 
orang-orang shalih, orang yang taat beribadah, para wali, ahli zuhud, para ulama, orang yang dekat dengan Allah, dan orang-orang yang mengikuti RasulNya. Ibnu Jarir dari Al-Hasan Basri dan Qatadah mengungkapkan bahwa maksud lafadz tersebut adalah Allah berfirman kepada malaikat semata-mata untuk memberikan informasi. Menurut Ibnu Jarir, Allah akan menjadikan khalifah di muka bumi sebagai pengganti dalam memutuskan perkara secara adil, khalifah tersebut adalah Adam dan mereka menempati posisi dalam ketaatan pada Allah serta pengambilan keputusan secara adil. Imam Al Qurtubi dan ulama lainnya menjadikan ayat ini sebagai dalil keharusan mengangkat seorang pemimpin dalam memutusakan perkara, melerai pertikaian, menumpas kedzaliman menegakkan hukum dan mencegah perbuatan keji dan munkar (Katsir, 2004, pp. 99-100).

\section{Tinjauan Teologis}

M. Quraish Shihab menjelaskan di dalam Tafsir Al-Misbah, bahwa QS. Al-Baqarah ayat 30 merupakan kelompok ayat yang diawali dengan penyampaian informasi Allah kepada malaikat tentang rencana penciptaan manusia di bumi. Dalam dialognya Allah menceritakan akan diciptakannya khalifah di dunia. Penyampaian ini bisa jadi setelah adanya proses penciptaan alam raya dan kesiapan adam sebagai makhluk pertama yang menempati bumi. Mendengar rencana tersebut malaikat bertanya tentang makna penciptaan. Mereka menduga bahwa khalifah ini akan membuat kerusakan dan pertumpahan darah. Dugaan tersebut berdasarkan pengalaman mereka sebelum tercipta manusia, makhluk tersebut berbeda dengan malaikat yang selalu bertasbih. Pertanyaan mereka itu juga bisa lahir dari penamaan Allah terhadap makhluk yang dicipta itu dengan khalifah. Kata khalifah pada mulanya berarti yang menggantikan atau yang datang sesudah siapa yang datang sebelumnya. Akan tetapi atas dasar ini, ada yang memahami kata khalifah di sini dalam arti yang menggantikan Allah dalam menegakkan kehendak-Nya dan menerapkan ketetapan-ketetapan-Nya, tetapi bukan karena Allah tidak mampu atau menjadikan manusia berkedudukan sebagai Tuhan. Allah bermaksud dengan pengangkatan itu untuk menguji manusia dan memberinya penghormatan. Namun ada yang memahami dalam arti yang menggantikan makhluk lain dalam penghuni bumi ini (Shihab, 2007, p. 140).

Penafsiran ayat al-Qur'an di atas memberikan faidah sebagai berikut: Pertama, adanya dialog antara Allah dan para malaikat tentang penciptaan manusia di bumi karena adanya perbedaan pandangan. Malaikat mengetahui keberadaan manusia di bumi dengan perkataan "sesungguhnya aku lebih mengetahui apa yang tidak kamu ketahui" Kedua, kedudukan manusia di muka bumi adalah sebagai khalifah Allah atau pengganti Allah yang diberi 
tugas untuk memelihara dan melestarikan alam, mengambil manfaat serta mengelola kekayaan alamnya terwujud kedamaian dan kesejahteraan manusia. Ketiga, Malaikat menyaksikan bahwa tugas kekhalifahan dilakukan oleh manusia, menurut malainkan dirinya lah yang pantas dan lebih berhak mengemban tugas dengan bukti mereka tidak diberi hawa nafsu, selalu bertasbih memuji Allah. Keempat, malaikat merasa ragu akan penciptaan manusia karena mereka khawatir jika manusia tidak taat pada Allah, tidak bertasbih bahkan menyebabkan kerusakan di muka bumi.

Uraian di atas secara gamblang menggambarkan konsep tugas hidup manusia sekaligus tujuan hidupnya. Dalam konteks hubungannya dengan Tuhan, manusia adalah hamba Allah, sementara dalam konteks hubungannya dengan alam ia adalah khalifah. Sehingga dapat dikatakan bahwa tujuan hidup manusia adalah pengabdian kepada Allah dan khalifah atau pemimpin di muka bumi.

Sebagai khalifah manusia diberi tanggung jawab mengelola alam, karena alam semesta diciptakan Allah untuk manusia. Sebagai wakil Allah manusia diberi otoritas ketuhanan, menegakkan kebenaran dan membasmi kebathilan, oleh karenanya manusia dilengkapi Allah dengan kelengkapan psikologis yamg sempurna, akal, hati syahwat dan hawa nafsu. Kesempurnan yang dimiliki manusia dapat mengarahkannya pada posisi yang mulia dan tidak menutup kemungkinan membawanya pada posisi yang rendah dibanding binatang. Hal ini sejalan dengan firman Allah Q.S Al-Hajj ayat 41:

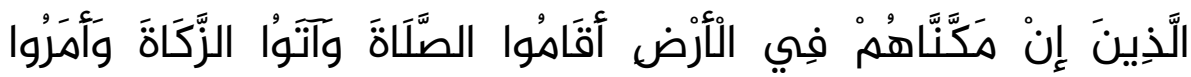

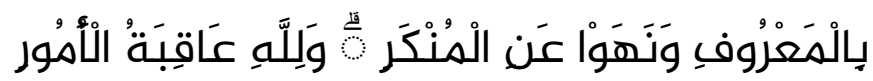

(yaitu) orang-orang yang jika Kami teguhkan kedudukan mereka di muka bumi niscaya mereka mendirikan shalat, menunaikan zakat, menyuruh berbuat ma'ruf dan mencegah dari perbuatan yang mungkar; dan kepada Allah-lah kembali segala urusan.

Ayat ini menafsirkan bahwa Allah menjanjikan manusia yang menolong agamanya, yaitu apabila dimenangkan atas musuh-musuhnya dan diteguhkan kedudukannya sebagai penguasa, taat pada perintah Allah, mendirikan shalat, menunaikan zakat, menyuruh manusia berbuat ma'ruf dan melarang berbuat keji, maka Allah akan membalas semua amal perbuatan manusia. Mendirikan shalat merupakan gambaran hubungan yang baik dengan Allah, sedangkan menunaikan zakat merupakan gambaran dari keharmonisan dengan sesama manusia. 


\section{Implikasi Tujuan Hidup Manusia terhadap Pendidikan Islam}

Tujuan hidup manusia sebagai abid (hamba) dan khalifah fi al-ardh, tentu berkaitan erat dengan pendidikan. Karena untuk membentuk pribadi yang mengetahui kewajibannya sebagai hamba Allah dan mengelola bumi perlu ditempuh dengan jalur pendidikan. Ibadah seseorang dapat diterima karena sesuai dengan kaidah yang telah ditetapkan oleh ajaran Islam berdasarkan pengetahuan dan pemahaman seseorang tersebut yang diperoleh dengan cara menuntut ilmu (pendidikan). Demikian halnya, kemampuan menjadi khalifah di muka bumi perlu ditunjang dengan pendidikan yang dimiliki.

Manusia diberikan amanah oleh Allah sebagai khalifah di muka bumi untuk memakmurkan dan menjaga alam semesta dari kehinaan dan kerusakan alam yang diciptakan manusia. Tugas dan fungsinya tersebut menuntut manusia untuk bersikap kreatif dan dinamis. Akal dan pengetahuan yang dimiliki manusia digunakan untuk kemaslahatan umat secara serasi dan seimbang. Untuk merealisasikan peran dan tugasnya tersebut dapat ditempuh melalui pendidikan. Pendidikan yang ditawarkan harus memberikan nilai-nilai ilahiyyah, dengan penanaman inilah manusia dapat menjalankan kekhalifahanya dengan baik. Pendidikan adalah proses perubahan sikap dan tingkah laku seseorang dalam mendewasakan dengan upaya pengajaran dan pelatihan.

Pendidikan merupakan upaya untuk meningkatkan martabat manusia yang terlahir dari ketidaktahuan, agar memiliki pengetahuan. Manusia dapat meningkatkan pengetahuannya karena Allah membekali manusia dengan indera dzahir dan batin, yang dibimbing oleh wahyu yaitu Al-Qur'an. Pendidikan bertugas mengembangkan potensi manusia semaksimal mungkin, dengan batas dan kemampuannya sehingga manusia menjadi kreatif dan dinamis. Pembentukan manusia sempurna ini akan tercapai jika dalam diri seseorang terjadi perpaduan harmonis dan integral antara dimensi-dimensi manusia seperti, intelektual, fisik, emosional dan etis (Al-Hamdani, 2017, pp. $1-2)$.

Pendidikan Islam merupakan sebuah proses membentuk manusia muslim yang mampu mengembangkan fitrah dalam merealisasikan fungsi dan tugasnya sekaligus merupakan tujuan hidupnya yaitu sebagai khalifah fil ardl. Dalam sebuah kekhalifahan terdapat empat poin penting yang saling berkaitan. Pertama, pemberi tugas yaitu Allah. Kedua, pemberian tugas dalam hal ini adalah manusia. Ketiga, tempat atau lingkungan manusia berada. Keempat, materi penugasan yang harus dilaksanakan (Shihab Q. , 2009, pp. 269-270).

Tugas kekhalifahan tersebut dinilai akan berhasil apabila materi penugasan dilaksanakan secara penuh dan tanggung jawab. Penjabaran tugas kekhalifahan harus selaras dan diangkat dari masyarakat itu sendiri, atas dasar 
inilah para ahli pendidikan sepakat bahwa tujuan pendidikan bagi suatu masyarakat atau negara tidak bisa diekspor dan impor dari suatu negara atau masyarakat. Poin penting dari pendidikan yang harus diperhatikan adalah penyusunan rancangan program pendidikan yang dijabarkan dalam kurikulum.

Kurikulum adalah segala kegiatan dan pengalaman pendidikan yang dirancang dan diselenggarakan oleh lembaga pendidikan dengan maksud untuk mencapai pendidikan yang telah ditetapkan. Berpedoman pada lingkup pendidikan yang akan dicapai maka kurikulum pendidikan Islam berorientasi pada empat hal yaitu: Tercapainya tujuan hablum minallah (hubungan dengan Allah), hablum minan naas (hubungan dengan manusia), hablum minal 'alam (hubungan dengan alam), hubungan manusia dengan dirinya sendiri. Keempat poin tersebut tercakup dalam materi kurikulum pendidikan Islam yang tersusun dalam mata pelajaran pendidikan Islam seperti Al-Qur'an Hadits, Fiqh, Aqidah Akhlak, Sejarah Kebudayaan. Mata pelajaran tersebut merupakan ruang lingkup kurikulum Pendidikan Agama Islam yang disajikan dan diselenggarakan lembaga pendidikan berbasis keagaman.

Pendidikan Islam tidak hanya menekankan pada orientasi intelektualisasi penalaran semata tetapi lebih pada pembentukan kepribadian yang utuh. Islam pada hakikatnya perfeksionalisme yaitu memahami kesempurnaan kehidupan. Allah berfirman dalam surat Al-Baqarah ayat 208 yang berbunyi:

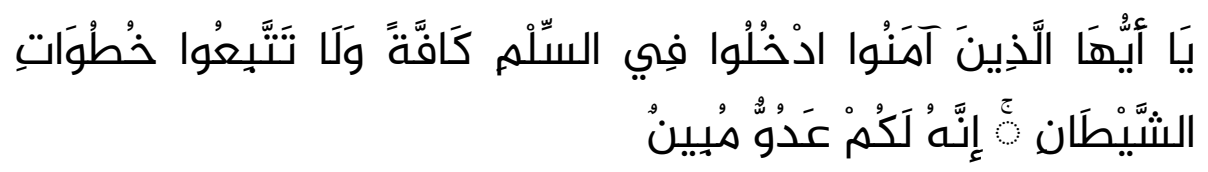

Hai orang-orang yang beriman, masuklah kamu ke dalam Islam keseluruhan, dan janganlah kamu turut langkah-langkah setan. Sesungguhnya syaitan itu musuh yang nyata bagimu.

Proses pendidikan Islam harus mempunyai landasan falsafah pendidikan demi mencapai tujuan yang menyeluruh serta dapat mengembangkan bakat kemanusiaan. Falsafah pendidikan inilah tentunya mempunyai corak dengan berlandaskan keimanan, sehingga proses pendidikan bersifat watak keagamaan. Yang mampu mengarahkan manusia pada pembentukan manusia yang beriman (Arifin, 2010, pp. 147-148). Tidak ada keraguan bagi umat Islam dalam menjalankan pendidikan Islam dengan berlandaskan pada al-Qur'an dan Hadis. Al-Qur'an berisi prinsip-prinsip yang memuat kegiatan dan usaha pendidikan, sementara Hadis sebagai landasan kedua berfungsi sebagai pelaksana dari ketentuan yang ditetapkan dalam al-Qur'an. Di dalamnya berisi tentang pedoman bagi kemaslahatan umat dalam berbagai aspek termasuk membina umat menjadi manusia yang seutuhnya. 
Pada hakikatnya tujuan akhir pendidikan Islam adalah membentuk insan kamil dengan corak keimanan yaitu terbentuknya muslim yang beriman, berakhlak mulia, berilmu yang senantiasa mewujudkan dirinya dengan baik untuk memperoleh kesempurnaan hidup disertai dengan sikap ketakwaan dan penyerahan diri pada Allah. Sebagai insan kamil tentunya manusia berhak mendapatkan pendidikan dalam rangka pengembangan, penyempurnaan dan pemeliharaan.

Dapat diambil kesimpulan bahwa pemahaman tujuan pendidikan Islam adalah menjadi manusia yang paripurna (insan kamil). Sebagai fungsi dan tugasnya sebagai abid (hamba Allah) dan khalifah $f i$ al-ardh, manusia mampu menjalankan tugasnya mengelola dan menjaga bumi dengan menjaga keharmonisan terhadap sesama serta makhluk lainnya.

\section{Kesimpulan}

Al-Qur'an menegaskan dua konsep tujuan hidup manusia di muka bumi, yaitu sebagai hamba Allah dan khalifah fil ardl. Tugas yang diberikan Allah mejadikan manusia makhluk yang istimewa dengan kelebihan potensi akal dan pengetahuannya untuk mengatur alam semesta. Kedua poin tersebut mengandung implikasi moral sehingga kehidupan manusia dibatasi oleh nilai dan etika ketuhanan. Manusia tidak diperkenankan menentang hukum Allah yang telah ditetapkan melainkan taat akan ketetapannya. Manusia harus mengiternalisasikan tugas kebudayaan dengan ciri kreativitas pada kehidupannya dan senantiasa menciptakan sesuatu yang baru sesuai dengan kebutuhan dan perkembangan masyarakat. Manusia bertugas mensyukuri nikmat yang diberikan Allah dengan upaya berkarya memakmurkan dan membudayakan bumi. Inilah konsep yang ditawarkan al-Qur'an dan as-sunnah mengenai dua term penting sebagai implikasi terhadap dunia pendidikan Islam menjadikan manusia sebagai insan kamil atau manusia paripurna.

\section{DAFTAR PUSTAKA}

Al-Hamdani, M. D. (2017). Konsep Dasar Pendidikan Bernuansa Islam. Bandung: Media Cendikia.

Al-Mahalli, J. (tt). Tafsir Al-Qur'an Al-Azhim. Semarang: Maktabah Toha Putera.

Arifin, M. (2010). Filsafat Pendidikan Islam. Jakarta: PT Bumi Aksara. 
Bafadhol, I. (2017). Tujuan Hidup Manusia Perspektif Al-Qur'an. Jurnal $A l$ Tadabbur: Jurnal Ilmu Al-Qur'an dan Tafsir.

Jazuli, A. S. (2006). Kehidupan dalam Pandangan Al-Qur'an. Jakarta: Gema Insani Press.

Katsir, I. (2004). Bandung: Sinar Baru Algesindo.

Katsir, I. (2004). Tafsir Ibnu Katsir, Penerjemah; M. Abdul Ghoffar E.M. . Bogor: Pustaka Imam Syafi'i.

Mujieb, M. A. (2009). Ensiklopedia Tasawuf Imam Al-Ghazali: Mudah Memahami dan Menjalankan Kehidupan Spiritual. Jakarta: Mizan Publika.

Priatna, M. (2005). Pemikiran Pendidikan Islam. Bandung: Sahifa.

Shihab, M. Q. (2007). Tafsir Al-Misbah (Vol. I). Jakarta: Letera Hati.

Shihab, Q. (2009). Membumikan Al-Qur'an: Fungsi dan peran Wahyu dalam Kehidupan Masyarakat. Bandung: Mizan.

Sukino. (2018). Konsep Sabar dalam Al-Qur'an. Jurnal Ruhama.

Sutisna. (2015). Syariah Islamiyah. Bogor: PT Penerbit IPB Press.

Trinurmi, S. (2015). Hakikat dan Tujuan Hidup Manusia dan Hubungannya dengan Tujuan Pendidikan Islam. Al Irsyad Al-Nafs, 57. 